\title{
Gabrielle Ferrieres - 'Jean Cavailles'. Combat philosopher. 1903-44.
}

Camille Akmut (trans.)

January 23, 2020

\author{
Abstract \\ The young Cavailles : Chapter 1. Childhood.
}


I had a friend [comrade]...

(Uhland 1813 quote: I couldn't give you my hand [but]

Forever and ever you remain My dear friend [comrade])

Born from the same love,

side by side, we grew up

Then he went his own solitary way, there where his genius took him but his heart staid behind, close to mine

And, then, finally he joined other men in battle [life's battle] A soldier's son, he was

(Uhland 1813 quote: A bullet flew He lied there, by my feet, as if the blood of my blood [chair de ma chair]) 


\section{CHILDHOOD}

We were three children, born at random wherever life took father. Jean was born in 1903, in Saint-Maixent, where our father taught geography at the Military School.

Saint-Maixent... the huge house, the garden full of mysteries, the large plane trees along the road of Poitiers, whose crunchy scales we liked to remove with our small hands, and the postman who my father had dubbed "Azur", [because] he wore a blue outfit. Tender past, just-warm-enough lukewarm happiness. The fog of semi-consciousness of tender childhood...

His teaching at the School enabled our father to display his gifts as a professor and speaker [conferencier] - of which Jean should inherit.

Under the impetuse of diectors like General Sarrail, and then General Lavisse, Saint-Maixent had been ranked first amongst all Officer Schools.

In turn, Gaston Boissier, Ernest Lavisse, Paul Lapie - the best of Sorbonne, Bordeaux and Poitiers professors - came to us in order to give these future officers a superior education, largely open to the (outside) world - the General Lavisse, brother of the [well-known] historian, liked to tease my father about the fidelity of his audiences.

Joffre, during his inspection round, had insisted on congratulating him personally.

In 1908, my father published an Atlas of modern campaigns [Atlas pour servir a l'etude des campagnes modernes], where in broad strokes he had highlighted in an intuitive manner the genius of Napoleon; it became a classic in the Army.

In 1909, my father became the youngest Lieutenant of France to be put on the board for further advancement to the grad of Captain.

We had to leave Saint-Maixent for Toulouse and join[ed] city life.

In Toulouse, we lived on "Damsels alley" [Allee des Demoiselles], (in) a villa between court and garden.

I had the privilege of occupying - alone but next to my grandmother, whose protection I enjoyed - a room with a view on the avenue.

Hearing the rumors of the city after the country silence of Saint-Maxent was delightful, to me. In particular, I liked the exhuberant passage of the tramway, which filled my room with its loud noise.

I very much liked to know if - in my absence - this cheerful noise still existed.

I remember having considered this problem seriously, and then one day I listened from outside the room, by the door, and there it was.

We did not go to class [were homeschooled] and every morning attended a lesson by our mother.

Her hands turned the pages of our notebooks (gracefully), and the elegance of her ways struck me. Her voice gave to our History of France the traits of a fairy tale.

Under her direction, Jean had also begun to study music, but while his ear was perfect, his voice [ability to play] was bad, a cause of much despair to him. 
He battled the clumsiness of his fingers so hard, that our mother got worried, and put him off the piano. The astounding musicial culture of Jean filled me with admiration; the influence that music has had on his entire life - I will talk about it again, later.

Our stay in Toulouse was to last 2 years. (...)

Our grandmother lived with us. I have often regretted not paying more attention to her stories : married young, she had followed her husband all the way to New Caledonia. In Noumea, during the Uprising of the Kanak people..., she was often left alone while our grand father left for inspection tours. She was brave, and when a sunstroke put her husband's life in danger, she took a boat to Europe, all the while pregnant with their third child.

In the middle of the Indian Ocean and under English patronage [pavillon anglais] a small girl was born. Our mother.

Back in Gascogne, my grand-father regained health little by little.

He was considerably older than his wife, a long colonial past had seriously altered his health for the worst, and any active life was henceforth forbidden to him.

It was during this time that he met a Protestant minister, Emilien Frossard, whose name has left a trace in Calivinist circles.

It was under the influence of this remarkable man, and after lengthy reflection, that my grandfather decided to convert to Protestantism. He died young still, leaving behind a 28 -year old widow and 4 small children.

I've left the year 1909, which saw our arrival in Toulouse. My father loved his work, as military commander. My mother often told us about how he would stay behind for his soldiers, making sure that everyone was alright, even when still wearing a drenched, freezing uniform.

How gay he was then, when his career was promising and we made him happy! He stayed late to play with us, and when we were given permission to have dinner with the adults ["the big people"], it was him who carried us, half-asleep, back to our beds (upstairs).

It was with his father, first, that Jean had learned to love his country. I can still see us, while still very small, attending 14th of July celebrations. On his horse "Fakir", our father spearheaded his troops [companie].

And, then came the trial [l'epreuve]. From the big military manoeuvres that had taken place on the burning plateau of Larzard, our father returned gravely ill. The month of July 1911 saw us leaving for the Pyrenees, and it was during this Summer that our brother Paul was struck with a typhoid fever and died. He was 4 years old.

Our parents' pain was terrible. Our father, whose health had improved, returned to an ill state, and we had to leave Toulouse for Pau, his native country; its climate, the doctors hoped, would help him recover.

A new garrison, but new was also our life.

Our father, defeated by despair and illness, never left his room, while our mother devoted herself to him.

Our little companion [Paul] had been taken away from us, our parents overcome by grief, we learned what pain and death was for the first time, and it was 
then that Jean and I turned to each other.

Following the period of inactivity at Pau, my father's health enabled him to take on a new job, first at Marmande, then Mont-de-Marsan, in recruitment.

From middle schools to high schools [colleges en lycees], Jean had a disjoint experience of secondary education.

At Mont-de-Marsan, he was often sick and kept at home, frequent and violent angina episodes interrupted his classes and momentarily halted his physical development. Nonetheless, by the end of the year, he came back carrying lots of wonderful books won from school prizes. He worked without great effort, alone, and still found time to organize our games of which he was the leader.

Our house was close to the Landes woods, this life-giving, strong forest, whose perfume I can no longer, even after all these years, inhale without feeling a pang of anguish [serrement de coeur].

Almost every day, we went on long walks together, in the gray sand of its alleys, bordered by blooming gorse and heather, depending on the season. Our dog Dick accompanied us.

At that time, we still shared the same room, a large room lit in the evening by the last lights emanating from a wooden fire, rendered mysterious and changing [mouvante] by it.

I had a friend, Marguerite C..., who was homeschooled like me : we, Jean and me, had included her in our circle / intimacy [intimite].

She wanted to be a Carmelite nun - Jean a missionary.

The three of us had founded a secret society, of which Jean was more some sort of king than a president.

Each of us bore a false name. Jean was "Hegesippe Laconismos". The goal of this society had been hard to find. Finally, we [settled on] simply protected the animals, but with what greatness and nobility!

Marguerite's parents owned a property [estate] in Chalosse, where we often ended spending the end of our vacation in Autumn. Jean, who was then 13 years old, had already won a reputation as an original and day-dreamer, that bothered/humiliated him a little.

Here is how he reported one of his misadventures to our parents :

I am hoping that weather in Mont-de-Marsant is not too hot, yesterday morning it rained, but it got better in the afternoon. That morning Mlle P... (the myope), daughter of the illustrious Ulysse P... ${ }^{1}$, had arrived. Rumor has it that a ghost living at Mrs P's house removes everything she has the honor of loosing in her excessive sense for order. M. P... ought to make a plaidoyer against him.

On the way back from a walk, Gabrielle noticed that I had a large ink stain on my pants, near the pocket. I had put my hand in my pocket : where my good but cap-less ink pen flew. My pocket was full of ink. I lost no time and put on my blue outfit. I had to change

\footnotetext{
${ }^{1}$ A lawyer from Mont-de-Marsan whose ridicule habits we made fun of.
} 
my underwear/boxer shorts too : there was a huge stain there as well, and now a tattoo on my leg too.

Upon seeing the stain, Mrs C... burst into laughter, a fit of the giggles soon took over everyone.

At the table, Mme C... cried from hilarity, only Marguerite and Ronron did not laugh, they must have found this all very unfitting.

Goodbye my dear parents, take care of yourselves, I love you with all of my heart, and grandmother too.

P.-S. Best greetings to Dick. ${ }^{2}$

It seems to me now that were both very young and old. War had broken out and we watched as our father despaired at his health, which kept him away from armed zones. He had repeatedly initiated procedures to join the Front, but each time the medical commissions refused him.

There are many ways to be a solider. This was the hardest for him... His thoughts never left the soldiers, comrades who one after the other were killed.

We shared in his suffering but we also secretely congratulated ourselves for being the witnesses of events that would one day make it the History of France.

I have found homework written by Jean, kept by our father, an essay on wheat, of which I have detached the conclusion :

O Wheat! Blood of countless heroes, fertilized the soil. To the blonde liqueur of the sun, the crimson taint of Men is now adjoined. Divine harvest, made from many, now go up to the blue sky; with your abundance, may you nourish France and in particular those among its children who fight to keep it. (...) chase the occupier away (...) And when peace returns, may your newfound beauty dignified enough so that you can surround the humble black crosses on the graves of those [who won't return]. (...)

I can't resist the pleasure of including another letter of Jean, written during one of our parents' trips, a display of his good heart :

Home is real empty without you, my dear dad and mom. During mornings, we don't go up to your room to say hello anymore. During dinner, the table is too big and no more tap on the cheek, my deer dad, and after dinner, we cannot go sit on your knees, dear mom.

There were two moments today where I felt that you were here : first, I heard walking on the pavement, and told myself merry : finally dad will be back, we'll be with him for a while.

At another point, I felt your hand on my back, beloved mom, I thought : "Keep straight".

I'm usually in a bad mood when you make such observations, but how good this all seems to me now that I'm without it.

${ }^{2}$ Letter from July 28th, 1916. 
These years also entailed our religious instruction and first communion. Here, I'd like to tell of our Hugenotes heredities which we owe to our father's side (of the family).

The mother of our father, Emma Cavailles, born Malan, came to visit us in Mont-de-Marsan every year, staying for a long period each time. (...), her very dark eyes, the lower side of her face all signified Italian origins.

The Malan family, guilty of embracing Vaudois heresy as early as the 12th century, was chased away from the lands of its ancestors, in the Alps of Luberon. (...)

A member of the English side of our family wrote this (...) :

(...) "The Malans". They lost everything, their lands and their lives, except eternal glory, out of love of Christ. To their children they left, at least, a good name/reputation, which is preferable to grand riches... ${ }^{3}$

It was the father of my grand mother, of whom we kept the stern portrait, who had wished to go back to France, his homeland. He went off alone, very young still and with no fortune, and joined the Bearn where he decided to settle down. The uprightness of his character soon gained him a priviledged situation. In that land, they said : "Honest like a Malan".

(...)

In this environment of mercheants and academics, the military vocation of my father had suprised some - and yet, this vocation was merely the conclusion of a long past of honors.

Our father was indeed the descendant of this Countess Malan of Merindol who, in the 12th c., had been buried alive because she had refused to abandon her faith. Jean too had inherited this past, of men and women defending their ideals at the risk of their lives, heir of the same Marie Durand who had written on the walls of her cell : "Resister" / (To) Resist. ${ }^{4}$

From childhood on, he shared that rigor.

We were still very young and shared the same bedroom.

Once all the evening ceremonies observed by our family were over, we went back up to our own domain, which we shared.

A sentence from the Scriptures [/l]es Ecritures] had left an impression on Jean : "Be on your guard, and pray, for you know neither the day and neither the time."

This order, he had taken by the letter and pretended to spend his nights praying. I heard him turn in his bed, resisting sleep, hitting his chest and sighing.

The drama that he experienced - this fight with oneself, this desire to kill the body to save the soul - filled me with anguish.

\footnotetext{
${ }^{3}$ Trans. note Gabrielle quotes from : Major C. H. Malan, South African Missions - a title she provides in English as well in the original.

${ }^{4}$ Marie Durant, heroine of the Reformation, locked up at age 18 in the Tower of Constance at Aigues-Mortes. She remained a prisoner there from 27 years (1732-1759).
} 
Come back morning and Jean was again the merry companion of our studies and games - our parents were ignorant of the secret shared but never revealed. Revealed only in the silence of our nights.

\section{2}

\section{ADOLESCENCE}

My father's knowledge of the English language was such that, in the Spring of 1918, he was called to the French-American Section of Bordeaux [la section franco-americaine a Bordeaux]. A new start, and a new high-school for Jean ... 